\title{
The polychaete community of the Fregene artificial reef (Tyrrhenian Sea, Italy): a 20-year study (1981-2001)
}

\author{
SARA MARZIALETTI ${ }^{1,3}$, LUISA NICOLETTI $^{1} \&$ GIAN DOMENICO ARDIZZONE $^{2}$ \\ ${ }^{I}$ ISPRA, Institute for Environmental Protection and Research, Via di Casalotti 300, 00166 Roma, Italy \\ ${ }^{2}$ Università di Roma "La Sapienza", P.le A. Moro 5, 00185 Roma, Italy \\ ${ }^{3}$ Corresponding author. E-mail: sara.marzialetti@isprambiente.it
}

\begin{abstract}
The artificial reef of Fregene, Italy, was built in 1981 as a multipurpose structure with the intent of protecting the coastal environment from illegal trawling and also improving fishery production. It is located at 10-14 m depth on a sandy-silty seabed in the Tyrrhenian Sea, $5 \mathrm{nmi}$ north of the outlet of the Tevere River (Latium, Italy) and $1.5 \mathrm{nmi}$ offshore the town of Fregene (Latium, Italy). The development of the polychaete community on the reef was studied from May 1981 to December 2001 in order to examine long-term community dynamics and verify to what extent changes in polychaete assemblage could depict the development of the benthic assemblage. At each sampling time, two standard surfaces of $400 \mathrm{~cm}^{2}$ were scraped from the vertical walls of the same block. Temporal changes in the development of the polychaete community were detected by univariate ( $\mathrm{S}, \mathrm{N}, \mathrm{ExpH}$ ', 1/Simpson, J') and multivariate (CLUSTER, nMDS) analysis of the faunal data. Functional structure of the community was also analyzed. Changes in the community structure were shown by an overall increasing trend in the total number of species and individuals. The 20-year development of the polychaete community was divided into five different phases representing different benthic assemblages on the reef: the first two periods correspond to settlement of pioneer species (1981-82); the third is a phase characterized by Mytilus galloprovincialis dominance and regression (1983-85); the fourth is a phase of mud accumulation between dead balanids, with the presence of laminar bryozoans (1991-92), and the last corresponds to a phase dominated by bryozoan bioconstruction (2001). The increased complexity in the benthic assemblage and substratum on the reef is also shown by an increased differentiation and distribution of polychaete functional groups. Increasing environmental heterogeneity on the reef is the basic factor that affected biodiversity by generating new niches that could be occupied by additional species with different ecology. The similarity of the benthic assemblage observed on the reef in 2001 with natural bioconstructions suggest that after two decades the ecological succession has lead to a settlement at a steady-state of equilibrium with the surrounding environment.
\end{abstract}

Key words: temporal evolution, artificial reefs, polychaete assemblages, functional groups, community development, species richness, biodiversity, ecological succession

\section{Introduction}

Artificial reefs have often been used as protection from coastal erosion and illegal trawling (Moreno et al. 1994) as well as a potential tool for reef restoration and rehabilitation and enhancement of local fisheries (Clark \& Edwards 1999). On a long time scale, studying benthic settlements during and after the colonization process, including origination on a new artificial substratum, can offer an 
important insight in understanding the most significant steps and changes in the structure of these communities (Riggio 1995; Somaschini et al. 1997; Nicoletti et al. 2007) and different phases of ecological successions (Svane \& Petersen 2001). However, even though early development of benthic communities on artificial substrata (fouling) has been intensively investigated (e.g., Riggio et al. 1985; Gravina et al. 1989; Judge \& Craig 1997; Connell 2000), knowledge of the late developmental stages of artificial reefs is still lacking (Svane \& Petersen 2001; Perkol-Finkel et al. 2006).

The development of the Fregene artificial reef has been monitored intermittently since its deployment in May 1981 (Ardizzone et al. 1989; Gravina et al. 1989; Ardizzone et al. 1994; Somaschini et al. 1997) and polychaete species patterns on the artificial reef were studied since the earliest stages of colonization (Gravina et al. 1989; Somaschini et al. 1997).

Polychaetes represent a numerically dominant macrobenthic taxon and, due to their wide adaptive strategies and the great number of trophic niches they occupy (Jumars \& Fauchald 1977; Bianchi \& Morri 1985), play a major role in the functional structure of benthic communities (Giangrande et al. 2005). Several studies demonstrated the suitability of polychaetes as indicators of community patterns in benthic invertebrate assemblages (Fresi et al. 1983; Olsgard \& Somerfield 2000; Tomassetti \& Porrello 2005) and they have also been proposed as surrogates for marine biodiversity analysis (Olsgard et al. 2003).

In this paper we (1) describe the biodiversity of the polychaete assemblage present on the reef in 2001 , (2) illustrate the changes in this assemblage over the 20 years since the deployment of the structure in 1981, and (3) verify that changes in the biodiversity of the polychaete fauna could in fact reflect the development of the benthic community as a whole.

The artificial reef. The artificial reef of Fregene is located in the Tyrrhenian Sea, 5 nmi north of the outlet of the Tevere River (Latium, Italy) and $1.5 \mathrm{nmi}$ offshore the town of Fregene (Latium, Italy). The reef was assembled in May 1981 as a multipurpose structure that was intended to protect the coastal environment from illegal trawling and to improve fishery production. The structure is placed at 10-14 m depth on a sandy-silty seabed. It is composed of 280 concrete cube-shaped blocks ( $2 \mathrm{~m}$ long on each side) arranged in 60 pyramidal groups of five blocks, four at the base and one at the top, covering in total a surface of six ha (Ardizzone \& Chimenz 1982; Ardizzone et al. 1989). Each cube has hollows and cavities molded into the shape in order to increase the surface/volume ratio (Bombace 1977).

The area is characterized as euthropic due to the nearness of the effluence of the Tevere River, which carries suspended material and a high organic load. The artificial reef is located in a transitional zone, characterized by abiotic factors typical of the infralittoral zone (high hydrodynamism) and circalittoral zone (reduced illumination) (Nicoletti et al. 2007).

\section{Materials and methods}

The benthic community on the artificial reef was monitored from May 1981 to October 1985 and from January 1991 to December 1992 (Ardizzone et al. 1989; Gravina et al. 1989; Ardizzone et al. 1994; Somaschini et al. 1997). New samples were collected in February, June, September, and December 2001. At each sampling event (26 in total over the 20 -year period), two standard surfaces of $400 \mathrm{~cm}^{2}$ were scraped by scuba divers from the vertical walls of the same block. Re-sampling of surfaces previously scraped was avoided by choosing different parts of the vertical walls. The collected material was fixed in $10 \%$ buffered formalin. Organisms were sorted and polychaetes, crustaceans, mollusks, and echinoderms were identified to the lowest possible taxonomic level (i.e., 
species) and counted. Here we analyze the data on the polychaete assemblage for 1981-2001 (Gravina et al. 1989; Somaschini et al. 1997; Nicoletti et al. 2007). Data were carefully examined and standardized at the family level when no accurate lower taxonomical identification was available.

Data analysis. Data analysis was carried out on abundance data pooled over and averaged from the two $400 \mathrm{~cm}^{2}$ surfaces scraped on each sampling date. Statistical analyses were performed using the PRIMER package, version 6 (Clarke \& Gorley, 2006). Temporal changes in the polychaete community structure were identified by univariate and multivariate analyses.

The structure of the species assemblage in a given area cannot be described only by the number of species $(\mathrm{S})$ regardless of the abundance because the number of individuals $(\mathrm{N})$ per species varies (Gray 2000; Ellingsen 2001). Indices that consider both species richness and the distribution of individuals among the species (Shannon-Wiener index, ExpH', the reciprocal of Simpson's index, and Pielou's $\mathbf{J}^{\prime}$ ) were therefore used as univariate measures of diversity. These indices express the heterogeneity diversity (evenness/equitability and dominance) (Gray 2000; Peet 1974). ExpH' expresses the distribution of the individuals among the species and is most affected by species in the middle of the species rank sequence, whereas $1 /$ Simpson is primarily a measure of dominance (Magurran, 1988). An additional aspect of diversity is evenness, or how the individuals are partitioned among the species. The most commonly used form is that of Pielou (1976).

A similarity matrix was constructed using the Bray-Curtis coefficient after a square-root transformation of the data (Bray \& Curtis 1957). Cluster analysis (hierarchical, agglomerative classification employing group average linking) and ordination by non-metric Multidimensional Scaling (nMDS) based on the similarity matrix were performed. The species making the greatest contribution to the division of sampling sites into the different groups identified by the multivariate analyses were determined using the similarity percentage procedure SIMPER (Clarke 1992). The similarity matrix was tested with the RELATE procedure (Clarke \& Gorley 2006) based on Spearman rank correlation over 9999 permutations. This procedure correlates the similarity matrix against a second matrix that the routine program constructs itself, referred to as seriation, where data are compared to a linear sequence to assess the extent to which samples follow a simple trend in time (Clarke \& Gorley 2006).

A special application of beta diversity was performed. Whittaker (1972) defined beta diversity ( $\beta$ $=\gamma / \alpha)$ as "the degree of change of species composition of communities along a gradient." It is not a measurement of species richness, but expresses the extent of change in species composition among the samples of a set, the turnover diversity (Gray 2000). The gradient along which we measured the change in taxonomical composition of the Fregene polychaete assemblage is time. We consider $\gamma$ as the total number of polychaete taxa collected on the reef throughout the whole sampling period (1981-2001). This number expresses the possible number of species in the area that could colonize a sample. $\alpha$ will be considered as the number of taxa at each sampling time. $\beta$ values will express therefore the proportion by which the whole sampling period is richer in the number of taxa than the different sampling times within it.

Functional groups are defined as groups of taxa that share a range of similar functional attributes (Bonsdorff \& Pearson 1999). To analyze the functional succession of the polychaete assemblage on the artificial reef we followed the scheme of polychaete guilds defined by Fauchald \& Jumars (1979) and Gambi \& Giangrande (1985a; 1985b) (Table 1). Since there was no evidence of algal settlement on the barrier throughout the study period, the taxa that could be included in the herbivorous group were considered as omnivorous. The functional group approach can offer a further explanation for the faunal diversity (Josefson 1985) and is here intended as a complement to statistical techniques (Bonsdorff \& Pearson 1999). 
TABLE 1. Main functional groups of polychaetes on the Fregene artificial reef.

Feeding type: B, burrowing detritivore; C, carnivore; O, omnivorous; F, filter feeder. Degree of motility: M, motile; D, semi motile; S, sessile. Feeding habit: J, jawed; T, tentaculate; X, other mechanism. The functional group code consists of three letters that refer in order to feeding type, degree of motility, and feeding habit (Fauchald \& Jumars 1979).

\begin{tabular}{cll}
\hline $\begin{array}{c}\text { Functional } \\
\text { Groups }\end{array}$ & \multicolumn{1}{c}{$\begin{array}{c}\text { Description } \\
\text { (trophic group, motility, feeding apparatus) }\end{array}$} & \multicolumn{1}{c}{ Example } \\
\hline BMX & Burrowers, motile, non jawed & Polyophthalmus pictus \\
CMJ & Carnivorous, motile, jawed & Harmothoe spinifera \\
CMX & Carnivorous, motile, non jawed & Phyllodocidae \\
FST & Filter feeders, sessile, tentaculate & Pomatoceros triqueter \\
ODJ & Omnivorous, discretely motile, tentaculate & Lysidice ninetta \\
SDT & Surface deposit feeder, discretely motile, tentaculate & Polydora spp. \\
SST & Surface deposit feeder, sessile, tentaculate & Terebella lapidaria \\
\hline
\end{tabular}

\section{Results}

\section{Polychaete assemblages}

From 1981-2001 the total number of individuals and taxa of polychaetes collected in samples taken on the artificial reef had an overall increasing trend (Fig. 1). From June 1981 to October 1985, 63 taxa of polychaetes were collected. Serpulidae (10 species) and Nereididae (4 species) were the most abundant families. The serpulids Pomatoceros triqueter (June 1981), Pomatoceros lamarckii, and Hydroides helmatus were the pioneer species that settled on the barrier in 1981. In 1982-1985 an increasing number of individuals and taxa of polychaetes were collected: serpulids (the most abundant were P. triqueter, P. lamarckii, and Hydroides pseudouncinatus pseudouncinatus) and other hard-bottom species (the nereidid Ceratonereis costae and the polynoid Harmothoe extenuata) were recorded both on the substratum of the reef and on the structures built by other sessile organisms such as mussels (Mytilus galloprovincialis) and barnacles (Balanus eburneus and Balanus perforatus). Other species that occur frequently in soft bottoms and eutrophic environments were recorded in the sediment trapped in the interstices among mussels valves, byssus filaments, and the calcareous structures of barnacles (Capitella capitata spp. complex, Mediomastus capensis, Cirratulus chrysoderma, Polydora hoplura, Heteromastus filiformis, Polydora ciliata, Dorvillea rubrovittata) (Ardizzone \& Chimenz 1982; Ardizzone et al. 1989; Gravina et al. 1989).

In 1991-1992, the polychaete community was composed of 49 taxa and 1443 individuals (Ardizzone et al. 1994; Somaschini et al. 1997; Ardizzone et al. 1998). The spionid Polydora ciliata was the most abundant taxon. Other species such as Terebella lapidaria and D. rubrovittata (common on soft substrates) and Serpula concharum, P. triqueter, H. ps. pseudouncinatus, and Lysidice ninetta (typical of hard substrata) were well represented.

In 2001 the population sampled on the reef comprised 104 taxa (Table 2), of which 94 were identified at the species level, and 6894 individuals. The most abundant taxa were spionids of the genus Polydora (1290 individuals), represented mainly by endolithic species, and Sabellaria spinulosa, S. concharum, H. ps. pseudouncinatus, L. ninetta, P. triqueter, P. lamarckii, Syllis truncata criptica (all typical of hard substrata), Aphelochaeta marioni, Lumbrineris funchalensis, T. lapidaria and Nematonereis unicornis (generally present in soft bottoms). Several of these species were also previously recorded (Gravina et al. 1989; Somaschini et al. 1997). 
TABLE 2. Taxonomical list of the Annelida Polychaeta sampled on the artificial reef of Fregene in 2001. The list has been compiled following the systematical order and the author's reference as listed in the Checklist for Annelida Polychaeta of the Italian Society for Marine Biology S.I.B.M. and the ERMS MARBEF database. http://www.sibm.it/CHECKLIST/principalechecklistfauna.htm; http://www.marbef.org/data/erms.php .

\begin{tabular}{|c|c|}
\hline \multicolumn{2}{|l|}{ Family and Species } \\
\hline Capitellidae & Lumbrineridae \\
\hline Notomastus aberans Day, 1957 & Lumbrineris coccinea (Renier, 1804) \\
\hline Opheliidae & Lumbrineris gracilis (Ehlers, 1868) \\
\hline Polyophthalmus pictus (Dujardin, 1839) & Lumbrineris labrofimbriata (Saint-Joseph, 1888) \\
\hline Paraonidae & Lumbrineris latreilli Audouin \& Milne Edwards 1834 \\
\hline Levinsenia gracilis (Tauber, 1879) & Scoletoma emandibulata mabiti (Ramos, 1976) \\
\hline Scalibregmatidae & Scoletoma funchalensis (Kinberg, 1865) \\
\hline Sclerocheilus minutus Grube, 1863 & Scoletoma tetraura $($ Schmarda, 1861$)$ \\
\hline Pholoidae & Sabellariidae \\
\hline Pholoe minuta (Fabricius, 1780) & Sabellaria spinulosa Leuckart, 1849 \\
\hline Pholoe dorsipapillatus (Marenzeller, 1893) & Serpulidae \\
\hline Pholoe synophtalmica Claparède, 1868 & Hydroides dianthus (Verrill, 1873) \\
\hline Polynoidae & Hydroides dirampha Morch, 1863 \\
\hline Harmothoe areolata Grube, 1860 & Hydroides helmatus (Iroso, 1921) \\
\hline Harmothoe spinifera (Ehlers, 1864) & $\begin{array}{l}\text { Hydroides pseudouncinatus pseudouncinatus } \\
\text { Zibrowius, } 1971\end{array}$ \\
\hline Chrysopetalidae & Pomatoceros lamarckii (Quatrefages, 1865) \\
\hline Chrysopetalum debile (Grube, 1855) & Pomatoceros triqueter (Linnaeus, 1758) \\
\hline Hesionidae & Serpula concharum Langerhans, 1880 \\
\hline Gyptis propinqua Marion \& Bobretzky, 1875 & Serpula lobiancoi Rioja, 1917 \\
\hline Kefersteinia cirrata (Keferstein, 1862) & Spiraserpula massiliensis (Zibrowius, 1968) \\
\hline Syllidia armata Quatrefages 1866 & Serpula vermicularis Linnaeus, 1767 \\
\hline Pilargidae & Spirobranchus polytrema (Philippi, 1844) \\
\hline Pilargis verrucosa (Saint-Joseph, 1899) & Vermiliopsis infudibulum (Philippi, 1845) \\
\hline Syllidae & Vermiliopsis striaticeps (Grube, 1862) \\
\hline Myrianida brachycephala Marenzeller, 1874 & Cirratulidae \\
\hline Myrianida cognetti Cinar \& Gambi, 2005 & Aphelochaeta marioni (Saint Joseph, 1894) \\
\hline Myrianida convoluta Cognetti, 1953 & Caulleriella bioculata (Keferstein, 1862) \\
\hline Myrianida edwarsi (Saint-Joseph, 1887) & Cirratulus cirratus (O. F. Müller, 1776) \\
\hline Myrianida prolifera O.F. Müller, 1788 & Dodecaceria concharum Örsted, 1843 \\
\hline Myrianida quindecimenta (Langerhans, 1884) & Timarete filigera (Delle Chiaje, 1808) \\
\hline Myrianida sp. cf quindecimentata & Terebellidae \\
\hline Dorvilleidae & Amphitrite rubra (Risso, 1826) \\
\hline Dorvillea (Dorvillea)rubrovittata (Grube, 1855$)$ & Amphitrite gracilis (Grube, 1860) \\
\hline Eunicidae & Nicolea venustula (Montagu, 1818) \\
\hline Eunice harassii Audouin \& Milne Edwards, 1834 & Terebella lapidaria Linnaeus, 1767 \\
\hline Eunice oerstedi Stimpson, 1853 & Polycirrinae \\
\hline Eunice pennata (O.F. Müller, 1776) & Polycirrus medusa Grube, 1850 \\
\hline Eunice schizobranchia Claparède, 1870 & Polycirrus sp. \\
\hline Eunice torquata Quatrefages, 1866 & Thelepodinae \\
\hline Eunice vittata (Delle Chiaje, 1828) & Thelepus setosus (Quatrefages, 1866) \\
\hline Lysidice collaris Grube, 1870 & Spionidae \\
\hline Lysidice ninetta Audouin \& Milne-Edwards, 1833 & Laonice cirrata, (M. Sars, 1851) \\
\hline Marphysa belli (Audouin \& Milne-Edwards, 1833) & Polydora spp. \\
\hline Marphysa fallax Marion \& Bobretzky, 1875 & Minuspio sp. cf. cirrifera \\
\hline Marphysa sanguinea (Montagu, 1815) & Pygospio elegans Claparède, 1863 \\
\hline Nematonereis unicornis (Grube, 1840) & \\
\hline
\end{tabular}




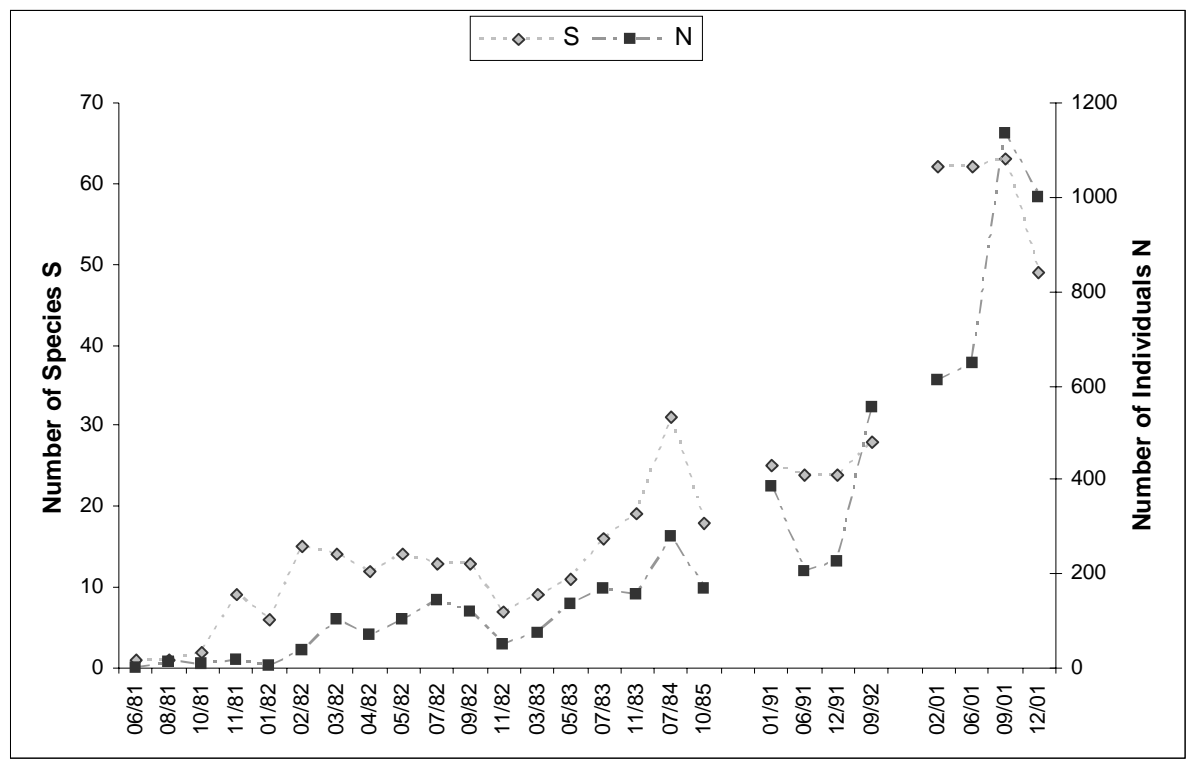

FIGURE 1. Temporal trend of species richness and abundance. Samples are ordered in temporal sequence from 1981 to 2001. N, number of individuals; S, number of species.

\section{Statistical analysis}

Heterogeneity indices encompass not only the number of species but also the distribution of individuals among the species. ExpH' (Fig. 2A) and 1/Simpson (Fig. 2B) showed an overall trend that followed the change in the number of species and individuals over time. Negative peaks are present, corresponding to high dominance by one or a few taxa. In the 1980s the dominant taxon was the family Serpulidae. The species $P$. triqueter mainly characterized the period February 1982-October 1985, together with other dominant species such as P. lamarckii, H. ps. pseudouncinatus, and S. concharum. In 1991-1992 and in 2001 the dominant taxon was the genus Polydora, which lives mainly as endolithic species inside the bryozoan structures. The third heterogeneity index, Pielou's equitability, reflected the same trend as the former ones (Fig. 2C).

Five main temporal groups based on clustering and nMDS stand out (Fig. 3A-B). The first cluster corresponds to data collected in June 1981 (Gr. 1), the second cluster corresponds to data collected from August 1981 to January 1982 (Gr. 2), the third cluster includes data from February 1982-October 1985 (Gr. 3), the fourth cluster includes data from 1991-1992 (Gr. 4) and the fifth cluster includes data from 2001 (Gr. 5). Figure 3 shows also that the pioneering stages of the community (Gr. 1 and Gr. 2) are highly separated from the others, while similarity among later sampling dates (Gr. 4 and Gr. 5) is higher, probably reflecting an increase in the stability of the community structure. The line that joins the sampling dates in Fig. 3B follows the trajectory of multivariate change through the 20 years and shows exactly how the change in polychaete settlement was continuous and constant over time. 

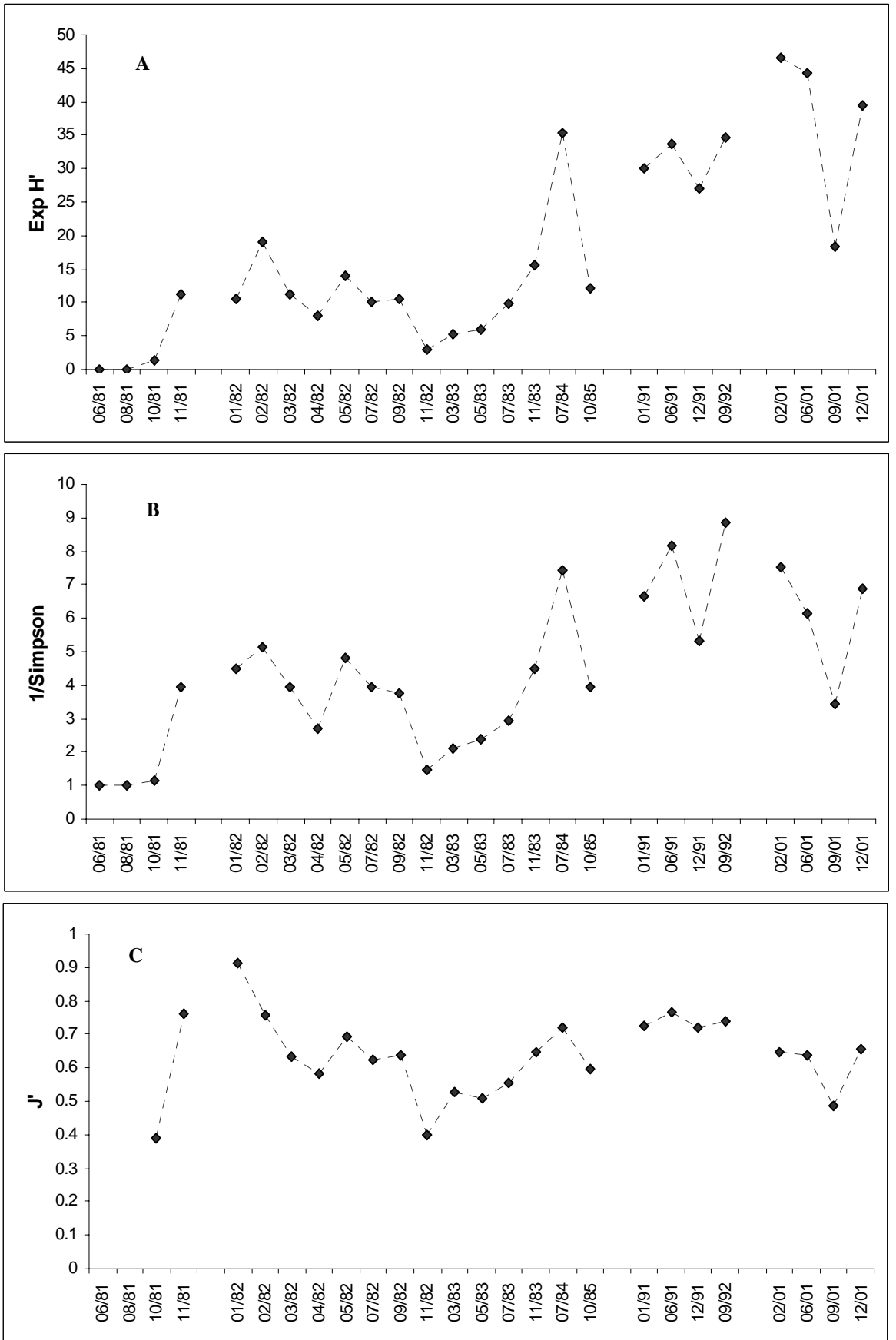

FIGURE 2. Univariate measures of community structure. A, the exponentiated form of the Shannon formula $\left(\mathrm{ExpH}^{\prime}\right)$ using log base 2; B, the reciprocal of Simpson's index (1/Simpson); (C) Pielou's index, J'. Samples are ordered in temporal sequence from 1981 to 2001. 
A

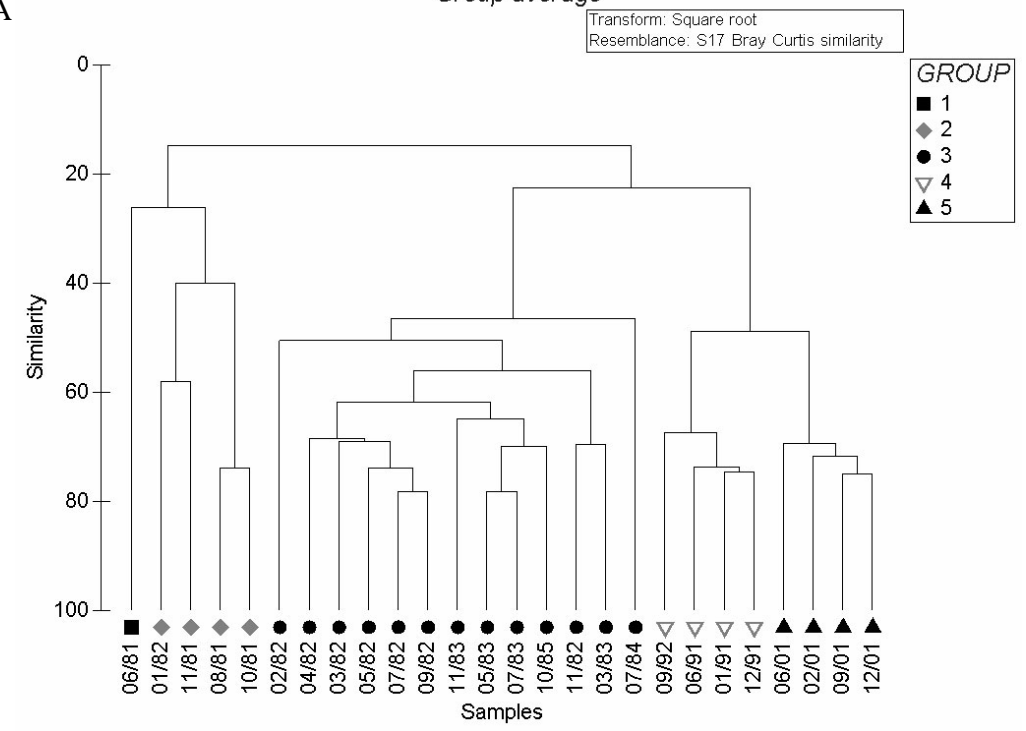

B

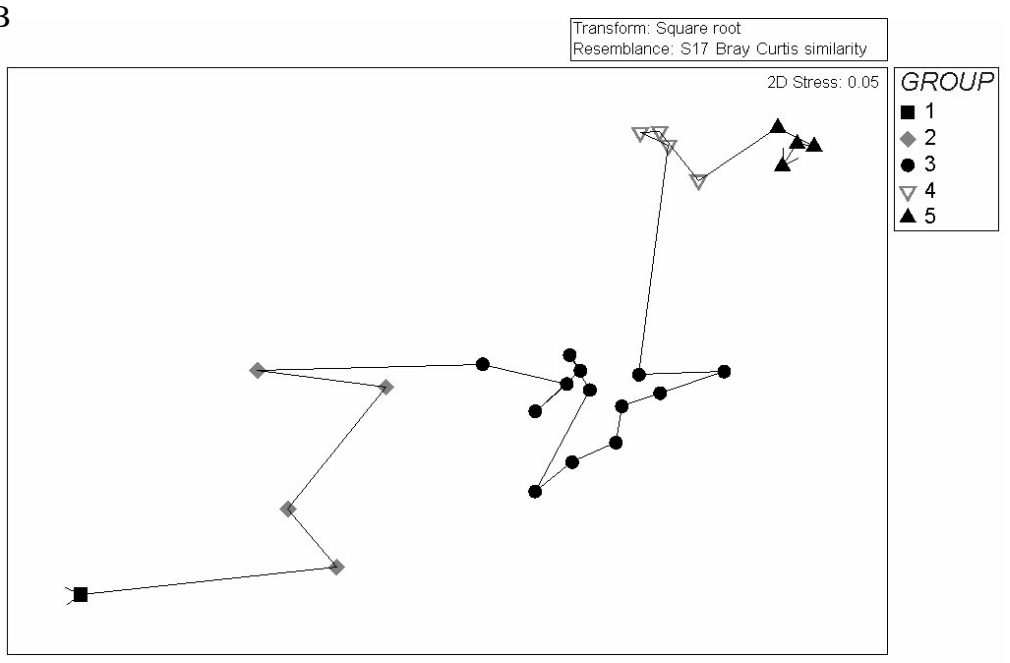

FIGURE 3. A, Hierarchical agglomerative clustering using group average linking; B, non-parametric Multidimensional Scaling (nMDS) ordination (stress $=0.05$ ). Both plots are based on square-root-transformed abundance data and Bray-Curtis similarities. 
Percentage of similarity within a group of samples and dissimilarity between groups identified by multivariate analysis are shown in Tables 3 and 4 . SIMPER analysis revealed the taxa contributing the most to the differentiation of the five phases in the transition of the polychaete assemblage on the artificial barrier. Gr. 1 was characterized by the presence of pioneer species, including the serpulid Pomatoceros triqueter. This species remained the characteristic one in Gr. 2 (92.32\% contribution of similarity) and also in Gr. 3 (33.97\%), along with other serpulid species ( $P$. lamarckii $19.59 \%$, H. ps. pseudouncinatus $16 \%$, and S. concharum $10.83 \%$ ). The genus Polydora distinguished the community in cluster Gr. 4 (16.09\%) and Gr. 5 (14.25\%). Gr. 4 is also differentiated by L. ninetta $(10.94 \%), H$. ps. pseudouncinatus $(10.02 \%)$, S. concharum $(8.16 \%), S$. truncata criptica (6.16\%), and T. lapidaria (5.16\%), while Gr. 5 is typified by S. spinulosa (9.08\%), sabellids (8.58\%), and other species such as H. ps. pseudouncinatus (4.93\%), A. marioni (4.85\%), S. concharum $(4.27 \%)$, and L. funchalensis $(4.17 \%)$. The RELATE procedure showed a good correlation between the similarity matrix and the seriation over time (Rho 0, 794, significance level of sample statistics $0.01 \%$ ).

TABLE 3. SIMPER percentage contribution to similarity of typifying taxa to groups identified by CLUSTER and nMDS analysis (similarity matrix on Bray-Curtis coefficient after square-root transformation of data, Bray \& Curtis 1957).

\begin{tabular}{cc}
\hline Group & SIMPER - percent similarity within group \\
\hline $\mathbf{1}$ & - \\
$\mathbf{2}$ & 48.73 \\
$\mathbf{3}$ & 58.39 \\
$\mathbf{4}$ & 71.77 \\
$\mathbf{5}$ & 71.16 \\
\hline
\end{tabular}

TABLE 4. SIMPER percentage contribution to dissimilarity between groups identified by CLUSTER and nMDS analysis (similarity matrix based on Bray-Curtis coefficient after square-root transformation of data, Bray \& Curtis 1957).

\begin{tabular}{ccccc}
\hline Group & \multicolumn{4}{c}{ SIMPER - percent dissimilarity between groups } \\
\hline & $\mathbf{2}$ & $\mathbf{3}$ & $\mathbf{4}$ & $\mathbf{5}$ \\
$\mathbf{1}$ & 73.79 & 94.86 & 97.97 & 99.01 \\
$\mathbf{2}$ & & 75.78 & 91.61 & 94.92 \\
$\mathbf{3}$ & & 73.65 & 81.20 \\
$\mathbf{4}$ & & & 51.09 \\
\hline
\end{tabular}

Figure 4 illustrates the trend of beta diversity values. Species turnover decreased over time reflecting the relative increase in the number of taxa found in the samples from 1981 to 2001. Nevertheless, the number of taxa at each sampling time $(\alpha)$ never reached the value of 133 taxa $(\gamma)$ sampled throughout the 20-year study (the highest number of taxa per sample was 63, in September 2001) stressing the evidence that species composition of the polychaete community changed over time. 


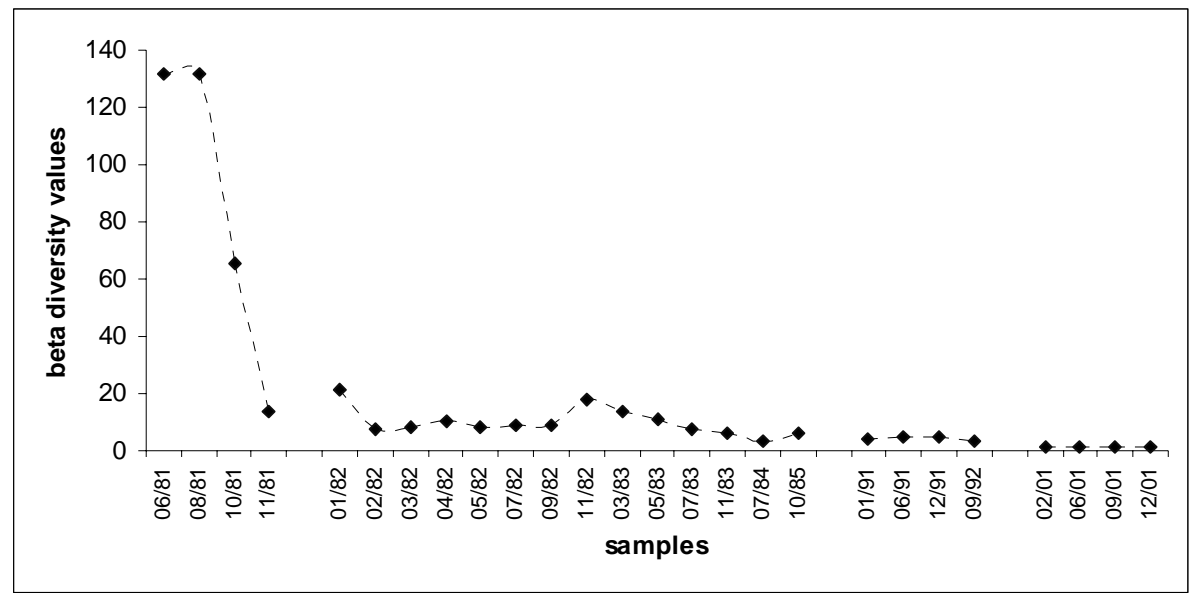

FIGURE 4. Temporal trend of beta diversity $(\beta)$ values calculated as $\beta=(\gamma / \alpha)$, where $\gamma$ is the total number of polychaete taxa collected on the reef throughout the whole sampling period (1981-2001) and $\alpha$ expresses the number of taxa at each sampling time. Samples are ordered in temporal sequence from 1981 to 2001.

\section{Functional groups}

Following Fauchald \& Jumars (1979) and Gambi \& Giangrande (1985a; 1985b), seven functional groups were identified among the polychaete assemblage on the artificial reef from 1981 to 2001(Table 1). Groups that had fewer than 10 individuals over the entire time interval were excluded from the analysis. The functional complexity of the assemblage increased with time (Fig. 5). Sessile tentaculate filter feeders (FST) such as serpulids and a few individuals of omnivores (ODJ) were the only groups present as pioneer species in 1981 (95\% and 5\% respectively). Reflecting the increasing species complexity, the other six groups appeared in the interval from 1982 to 1985, although the FST remained predominant $(85 \%)$. The abundance of this group remained high throughout the 20year interval, as is to be expected for a hard substratum settlement (42\% in 1991-1992 and $48 \%$ in 2001). Nevertheless, other groups such as tentaculate surface deposit feeders (discretely motile and sessile, SDT and SST, in total 31\% in 1991-1992 and 34\% in 2001), and carnivorous (jawed and not, CMJ and CMX, in total 9\% in 1991-1992 and 2001) became progressively more abundant. Omnivores reached the highest abundances in 1991 (17\%) and decreased again in 2001 (9\%), even though their presence remained significant. Motile burrowers (BMX) made their first appearance in 1982-1985, and further decreased.

\section{Discussion}

The multivariate analysis based on the Bray-Curtis similarity matrix clustered the community into five main stages or successional events that corresponded to the main stages observed for the entire fauna (Nicoletti et al. 2007).

When in 1981 the artificial reef of Fregene was deployed on sandy-silty bottoms it suddenly constituted an "island habitat" (Simberloff \& Abele 1982) in an area of low heterogeneity. Recruitment onto artificial reefs and other island habitats happens primarily by settling of pelagic larvae (Svane \& Petersen 2001) and is favored by a series of conditions such as availability of space, 
no competition for food, and scarce predation. The first stages of recruitment and colonization on the new structure were characterized by the presence of few pioneer polychaete species and individuals (i.e. Serpulidae). The first polychaete species that colonized the new substratum was the serpulid Pomatoceros triqueter. This species remained the dominant taxon in all samples collected from 1981 to 1985 . Hydroids, barnacles, and mollusks were the only other benthic taxa present on the reef at the time (Nicoletti et al. 2007). The great availability of new substratum soon attracted more hardbottom invertebrates typical of eutrophic waters that quickly colonized the reef. The period 1982-1985 corresponded to a phase of the benthic assemblage defined as "Mytilus galloprovincialis dominance and regression phases" (Gravina et al. 1989; Somaschini et al. 1997; Nicoletti et al. 2007). This mussel became the dominant species on the reef soon after the deployment of the structure. Its presence immediately altered the substratum, which became more varied, leading to an increase in the associated polychaete assemblage (1982-1983). Moreover, the heterogeneity of the substratum included sediments that remained trapped among the valves of the Mytilus and the mussel population rapidly declined (1984-1985) and died. The increasing presence of soft sediment caused changes in the polychaete community composition. In 1982 polychaete diversity first decreased and then immediately increased (1983-1985), with the added presence of soft-bottom species (Gravina et al. 1989; Somaschini et al. 1997; Nicoletti et al. 2007). Vance (1988) observed that senescence of early residents will eventually release empty space, but variable recruitment of new species (by migration from the surrounding area or by additional larval settling) can lead again to a high degree of dominance and initiate subsequent development stages (Pearson \& Rosenberg 1978; Vance 1988; Svane \& Petersen 2001). The polychaete (and benthic in general) assemblage observed on the reef from 1983 to 1985 was a transitional community of secondary opportunistic species, whose presence led to a strong modification of the substratum. The turnover of some of the resident species favored the recruitment of new colonizers. New niches were readily occupied by species with different ecological strategies, which continued the ecological succession.

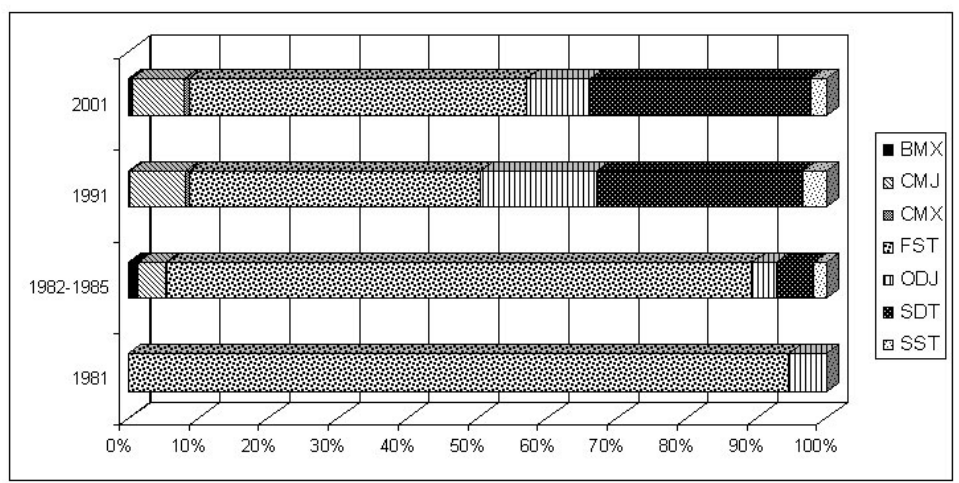

FIGURE 5. The changing distribution of the functional groups found in the four main development stages of the artificial reef of Fregene.

The polychaete assemblage of 1991-1992 corresponded to a new kind of benthic settlement, when the species richness and diversity values were significantly higher compared to samples from 1981-1985. The substratum had changed once more: mussels were absent and soft sediment was trapped among dead barnacles. The bryozoans Schizoporella errata and Scrupocellaria reptans were the only sessile species extensively distributed on the reef covering the substratum with flat laminar 
colonies (Somaschini et al. 1997). The polychaete community included species typical of hard bottoms as well as species normally found in soft sediment. The dominant species was Polydora ciliata, which usually burrows into substrata containing calcium carbonate and is also found in muddy sediments (Hill 2007). Species richness and diversity values were significantly higher than for samples collected from 1981 to 1985.

In 2001 the benthic community was characterized by complex bioconstructions of bryozoans $S$. errata and Turbicellepora magnicostata. A similar pattern of bioconstruction was described by Cocito et al. (2000) for some populations of $S$. errata on natural substrata. This bryozoan is described as an ecosystem engineer, a strong interference competitor able to overgrow other organisms such as hydroids, balanids, and mussels by expanding above them. Erect organisms may resist overgrowth, becoming a frame for erect formations while others become "ghost-frame builders" disappearing under layers of the mineralized bryozoan skeletons (Cocito et al. 2000). These structures can contain small cavities and shells of dead mussels and barnacles that fill with sediment, as is the case of the bioconstruction observed on the artificial reef of Fregene in 2001.

Successional theory maintains that a succession once initiated will proceed to an eventual equilibrium community and will be self-sustaining (Ellis 2003). In 2001 the increased heterogeneity and volume of substrata on the reef led to the existence of a complex associated biota including an increase in the polychaete community in both the total number of individuals and richness of species. Hard-bottom species such as Serpulidae and S. spinulosa were found on epibioses on the biogenic structures while soft-bottom species (L. ninetta, L. collaris, N. unicornis, L. funchalensis, A. marioni, and T. lapidaria) were present in the sediment-filled interstices and spaces left by dead organisms (mussels and barnacles). Other species, such as those belonging to the genus Polydora (e.g., P. ciliata) bore into calcareous structures and live inside dead balanids and bryozoans. A case comparable to the succession of Fregene's benthic assemblage was observed by Schuhmacher (1988) who described the 20-year ecological development of benthic epibiosis on a granite breakwater in tropical waters. After an initial colonization by pioneer species, he observed a "pioneer frame-building phase" of corals and mussels that produced more heterogeneity and finally a "frame-building phase" where dead corals were overgrown by coralline algae and bryozoans. Pearson \& Rosenberg (1978) stated that ecological succession is equivalent to a process of accumulating information that will take into account possible changes of the environment and even control and modify the environment. They called this process "biological accommodation", when a group of species is replaced by a better adapted one, as is the case of Fregene's artificial reef. As the succession proceeded, the number of species adapted to survive unpredictable perturbation (i.e. opportunistic species) decreased. Species turnover diminished progressively over time and the settlement that was present on the reef in 2001 appeared more stable, as shown by the reduced variation between the assemblages between 1991/92 and 2001. A "normal" or "climax" community depends therefore less on environmental variation and regional scale processes (such as dispersal and number of possible colonizers) and more on the interaction at a smaller, local scale between the epibiotic species themselves (competition for food and space, predation etc.) (Vance 1988; Palmer et al. 1996).

The pattern of change in the number of functional groups and in the distribution of the individuals within the different groups is further evidence that reflects the increase in community differentiation and the ecological succession. In 1981, during the pioneer species colonization phase, the trophic structure of the population was simple and dominated by filter feeders, such as serpulids, and some omnivorous species, which adapted well to life on a new hard substratum. Only one year after the artificial reef deployment (1982), seven different functional groups were present within the polychaete assemblage. The presence of these seven groups remained constant throughout the whole 
study period, even though the distribution of the individuals among the different groups changed. This can be interpreted as a response of the community as a whole to the changes in the structural complexity towards the achievement of steady-state equilibrium. No substantial differences were observed between the functional structure present on the reef in 1991-1992 and in 2001. In both 1991 and 2001 the trophic structure of the polychaete assemblage was characterized mainly by surface deposit feeders (SDT and SST) and filter feeders (FST), even though carnivores (CMJ and CMX) and omnivores (OMJ) were also well represented. No algae were found on the artificial reef throughout the entire study (Ardizzone et al. 1989; Targusi et al. 2005). This could be due to the fact that water transparency in the area where the artificial structure is positioned is minimal because of the effluence of the Tevere River, which carries suspended material and a high organic load (Nicoletti et al. 2007). Consequently, no herbivores were found on the reef.

The location of the artificial reef in a transitional zone, characterized by abiotic factors typical of the infralittoral zone (high hydrodynamism) and circalittoral zone (reduced illumination because of high organic and inorganic load) (Nicoletti et al. 2007) allows the dominance of both filter-feeders and deposit-feeders organisms, which normally occupy different environments. Carnivores (and omnivores) maintained a constant percentage between 1991-2001. The functional group approach was a useful complement to statistical analysis of the fauna in detecting the evolution of the settlement and in identifying the changes in biological relationships underlying benthic communities over time.

We cannot assess whether or not the community present on the reef has reached a "climax" state, even though the assemblage appeared to be in a steady-state equilibrium with the surrounding environmental conditions. The physical and biological environment on which an artificial reef is placed strongly influences the subsequent phases of recruitment, colonization, and development of fouling communities (Svane \& Petersen 2001). The 20-year study at Fregene revealed that the growing heterogeneity of the substratum was the driving factor for the increase in biodiversity on the artificial reef. Nicoletti et al. (2007) related the change over time of the benthic assemblage of the artificial reef with the change in sediment transport rates in the Tevere river. The progressive decrease in depositional rates and the position of the structure enabled the development on the reef of a bioconstruction similar (both in morphology and composition) to a "coralligenous bioconstruction". There was, however, a significant presence of soft-bottom species due to the peculiar morphology of the bryozoan construction patterns and to the conditions of the area. Nevertheless, a new change in the river flow and in the rate of sediment transportation would probably again modify the structure of the community on the reef.

The similarity of the benthic settlement observed on the reef in 2001 with natural bioconstructions (Cocito et al. 2000) suggested the hypothesis that after two decades the settlement of the artificial structure could mimic natural communities. Comparison with natural reefs is important in order to assess the performance of artificial reefs, because natural variations must be taken into account (Svane \& Petersen 2001). Pekrol-Finkel et al. (2005; 2006) studied communities on adjacent artificial and natural reefs and found that "young" artificial reefs (ca. 20 years) may have similar species composition to the natural reefs and that given several decades, an artificial reef will mimic adjacent natural reefs if it possesses similar structural features to the surrounding ones. Svane $\&$ Petersen (2001) observed that several studies have pointed out how artificial substrata show successional patterns without reaching a dominating final climax and stated therefore that artificial reefs must be considered as "fouling objects", consistently more unpredictable than natural substrata. Fouling assemblages on artificial reefs may converge in time with natural substrata but the time scale to reach the same stability and level of diversity remains to be clarified (Svane \& Petersen 2001). Further investigations on the artificial reef of Fregene could be useful to assess whether the 
community has really reached a climax/steady-state and, if compared with natural hard-bottom communities that live in similar environments, verify if, and to what degree, the community of the artificial reef is mimicking natural ones.

The polychaete community depicted well the ecological succession of the complete benthic settlement in response to biotic and abiotic changes displaying changes in species composition and in functional structure. This confirms the key role of these organisms in understanding community patterns in benthic invertebrate assemblage.

This analysis of the polychaete and benthic community succession, in addition to Nicoletti et al. (2007), provides a contribution towards a better understanding of ecological processes as well as useful data to plan future artificial reef projects.

\section{Acknowledgements}

We thank Dr. Luigi Musco for his assistance in the identification of the Syllidae family and Paolo Tomassetti for his critical comments on the laboratory activities and on the statistical analysis. The field component of this study would not have been possible without the assistance of Andrea Belluscio. Thanks to Monica Targusi for sharing long sorting activities. Finally, we wish to thank two anonymous referees and the editor Dr. Nancy Maciolek for their critical work on the manuscript.

\section{References}

Ardizzone, G.D. \& Chimenz, C. (1982) Primi insediamenti bentonici della barriera artificiale di Fregene. Atti del Convegno Progetto Finalizzato C.N.R. Oceanografia e Fondi Marini, Rome, November 1981, 165-181.

Ardizzone, G.D., Gravina, M.F. \& Belluscio, A. (1989) Temporal development of epibenthic communities on artificial reefs in the central Mediterranean Sea. Bulletin of Marine Science, 44 (2), 592-608.

Ardizzone, G.D., Gravina, M.F. \& Gusso Chimenz C. (1994) A ten years research on marine artificial habitat for fishery purposes. Contributions to Animal Biology, Halocynthia Association, 47-53.

Ardizzone, G.D., Belluscio, A., Gravina, M.F., Gentiloni, P. \& Somaschini, A. (1998) Organismi bentonici e comunità ittiche di substrati artificiali in acque eutrofiche (Fregene) e oligotrofiche (Ponza) (Mar Tirreno centrale). Biologia Marina Mediterranea, 5 (3), 1783-1792.

Bianchi, C.N. \& Morri, C. (1985) I policheti come descrittori della struttura trofica degli ecosistemi marini. Oebalia, vol. XI, N.S., 203-214.

Bombace, G. (1977) Aspetti teorici e sperimentali concernenti le barriere artificiali. In: Cinelli, F., Fresi, E. \& Mazzella, L. (Eds), Atti del IX Congresso della Società Italiana di Biologia Marina, Ischia, Naples, pp. 29-41.

Bonsdorff, E. \& Pearson, T.H. (1999) Variation in the sublittoral macrozoobenthos of the Baltic Sea along environmental gradients: a functional group approach. Australian Journal of Ecology 24, 312-326.

Clarke, A. (1992) Is there a latitudinal diversity line in the sea? Trends in Ecology \& Evolution 7, 286-287.

Clark, S. \& Edwards, A.J. (1999) An evaluation of artificial reefs structures as tools for marine habitat rehabilitation in the Maldives. Aquatic Conservation: Marine and Freshwater Ecosystems, 9, 5-21.

Clarke, K.R. \& Gorley, R.N. (2006) Primer V 6: User Manual/Tutorial. PRIMER-E: Plymouth. 190 pp.

Cocito S., Federghini F., Morri C. \& Bianchi C.N. (2000) Patterns of bioconstruction in the cheilostome Schizoporella errata: the influence of hydrodinamics and associated biota. Marine Ecology Progress Series, 192, 153-161.

Connell, S.D. (2000) Floating pontoons create novel habitats for subtidal epibiota. Journal of Experimental Marine Biology and Ecology, 247, 183-194.

Ellingsen, K.E. (2001) Biodiversity of a continental shelf soft sediment macrobenthos community. Marine Ecology 
Progress Series, 218,1-15.

Ellis, D.V. (2003) The concept of "sustainable ecological succession"; and its value in assessing the recovery of sediment seabed biodiversity from environmental impact. Marine Pollution Bulletin, 46, 39-41.

Fauchald, K. \& Jumars, P.A. (1979) The diet of worms: a study of polychaete feeding guilds. Oceanography and Marine Biology: an Annual Review, 17, 193-284.

Fresi, E., Colognola R., Gambi, M.C., Giangrande, A. \& Scardi, M. (1983) Ricerche sui popolamenti bentonici di substrato duro del Porto di Ischia. Infralitorale fotofilo: Policheti. Cahiers de Biologie Marine 24, 1-19.

Gambi, M.C. \& Giangrande, A. (1985a) Analisi della struttura trofica del popolamento dei policheti nei fondi mobili di due aree del Mar Tirreno. Oebalia, vol. XI, N.S., 215-222.

Gambi, M.C. \& Giangrande, A. (1985b) Caratterizzazione e distribuzione delle categorie trofiche dei policheti nei fondi mobili del Golfo di Salerno. Oebalia, vol. XI, N.S., 223-240.

Giangrande, A., Licciano, M. \& Musco, L. (2005) Polychaetes as environmental indicators revisited. Marine Pollution Bulletin 50, 1153-1162.

Gravina, M.F., Ardizzone, G.D. \& Belluscio, A. (1989) Polychaetes of an Artificial Reef in the Central Mediterranean Sea. Estuarine, Coastal and Shelf Science, 28, 161-172.

Gray, J.S. (2000) The measurement of marine species diversity, with an application to the benthic fauna of the Norwegian continental shelf. Journal of Experimental Marine Biology and Ecology 250, 23-49.

Hill, J.M. (2007) Polydora ciliata. A bristleworm. Marine Life Information Network: Biology and Sensitivity Key Information Sub-programme. Plymouth: Marine Biological Association of the United Kingdom. [cited 26/11/ 2008]. Available from: 〈http://www.marlin.ac.uk/species/Polydoraciliata.htm>

Josefson, A.B. (1985) Distribution of diversity and functional groups of marine benthic infauna in the Skagerrak (eastern North Sea) - Can larval availability affect diversity? Sarsia 70, 229-249.

Judge, M.L. \& Craig, S.F. (1997) Positive flow dependence in the initial colonization of a fouling community: results from in situ water current manipulations. Journal of Experimental Marine Biology and Ecology, 210, 209-222.

Jumars P.A. \& Fauchald, K. (1977) Between-community contrasts in successful polychaete feeding strategies. In: Coull, B.C. (Ed.) Ecology of Marine Benthos, University of South Carolina Press, Columbia, South Carolina, pp.1-22.

Magurran, A.E. (1988) Ecological Diversity and its Measurement. Princeton University Press, Princeton, New Jersey, $179 \mathrm{pp}$.

Moreno, I., Roca, I., Renones, O., Coll, J. \& Salamanca, M. (1994) Artificial Reef Program in Balearic Waters (Western Mediterranean). Bulletin of Marine Science, 55 (2-3), 667-671.

Nicoletti, L., Marzialetti, S., Paganelli D. \& Ardizzone, G.D. (2007) Long term changes in a benthic assemblage associated with artificial reefs. Hydrobiologia, 580, 233-240.

Olsgard, F. \& Somerfield, P.J. (2000) Surrogates in benthic investigations. Which taxonomic units? Journal of Aquatic Ecosystem Stress and Recovery 7, 25-42.

Olsgard, F., Brattegard, T. \& Holthe, T. (2003) Polychaetes as surrogates for marine biodiversity: lower taxonomical resolution and indicator groups. Biodiversity and Conservation, 12, 1033-1049.

Palmer M.A., Allan J.D. \& Butman C.A. (1996) Dispersal as a regional process affecting the local dynamics of marine and stream benthic invertebrates. Trends in Ecology \& Evolution, 11, 322-326.

Pearson, T.R. \& Rosenberg, R. (1978) Macrobenthic succession in relation to organic enrichment and pollution of the marine environment. Oceanography and Marine Biology: An Annual Review, 16, 229-311.

Perkol-Finkel, S., Shashar, N. \& Benayahu, Y. (2006) Can artificial reefs mimic natural reef communities? The role of structural features and age. Marine Environmental Research, 61, 121-135.

Perkol-Finkel, S. \& Benayahu, Y. (2005) Recruitment onto a planned artificial reef: shifts in community structure one decade post deployment. Marine Environmental Research, 59, 79-99.

Peet, R.K., (1974) The measurement of species diversity. Annual Review Ecological Systems, 5, 208-307.

Pielou, E.C. (1976) Population and community ecology. Gordon and Breach, Chicago, 424 pp.

Riggio, S., Gristina, M., Giaccone, G. \& Badalamenti, F. (1985) An eighteen months survey of the artificial reef of 
Terrasini (N/W Sicily): the Invertebrates. Oebalia, 11, N.S., 427-437.

Riggio, S. (1995) Le barriere artificiali e l'uso conservativo della fascia costiera: risultati dei "Reefs" nella Sicilia N/O. Biologia Marina Mediterranea, 2 (1), 129-164.

Schuhmacher, H. (1988) Development of coral communities on artificial reef types over 20 years (Eilat, Red Sea). Proceedings of the 6th International Coral Reef Symposium, Townsville, Australia, 3, 379-384.

Shannon C.E. \& Weaver, W. (1949) The mathematical theory of communication. Urbana: University of Illinois Press, 122 pp.

Simberloff, D. \& Abele, L.G. (1982) Refuge design and island biogeography theory: effects of fragmentation. American Naturalist, 120, 41-50.

Somaschini, A., Ardizzone, G.D. \& Gravina, M.F. (1997) Long-term changes in the structure of a polychaete community on artificial habitats. Bulletin of Marine Science, 60 (2), 460-466.

Svane, I. \& Petersen, J.K. (2001) On the problems of epibioses, fouling and artificial reefs, a review. Marine Ecology, 22 (3), 169-188.

Targusi, M., Ardizzone, G.D., Bondanese, C., Chimenz, C., La Porta, B., La Valle, P., Lattanzi, L., Marzialetti, S. \& Nicoletti, L. (2005) Benthic assemblages on artificial reefs: Ponza and Fregene (Latium, Italy). Biologia Marina Mediterranea, 12(1), 436-350.

Tomassetti, P. \& Porrello, S. (2005) Polychaetes as indicators of marine fish farm organic enrichment. Aquaculture International, 13 (1-2), 109-128.

Vance, R.R. (1988) Ecological succession and the climax community on a marine subtidal rock wall. Marine Ecology Progress Series, 48, 125-136.

Whittaker R.H. (1972) Evolution and measurement of species diversity. Taxon, 21, 213-251. 